\title{
Greenpeace defiant in face of threat from oil company
}

[LONDON] The environmentalist group Greenpeace says it has no intention of scaling down its disruption of oil exploration, despite being threatened with bankruptcy by the oil giant British Petroleum (BP).

A court in Edinburgh, Scotland, last week froze Greenpeace's UK bank accounts, issued

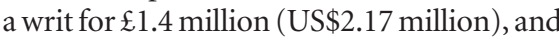
indicted four activists for losses incurred from delays caused by Greenpeace's week-long occupation of an oil platform earlier this month. The activists had chained themselves to a mobile drilling platform which was being towed to the Foinaven oilfield. The oilfield is part of new reserves west of the Shetland islands, known as the Atlantic Frontier.

$\mathrm{BP}$ withdrew its damages claim after two days, as well as charges against three of the activists, in return for an undertaking that Greenpeace would stay away from Foinaven. The company had earlier tried to obtain an assurance that Greenpeace would not obstruct BP activities in the whole of the Atlantic Frontier. But Greenpeace said it would not give such an undertaking.

Marcus Rand, a Greenpeace campaigner, says the pressure group may continue direct action in the Atlantic Frontier's other main oilfield, Schiehallion. He says Greenpeace will try to prevent all new oil exploration on the grounds that increased fossil fuel use will contribute to climate warming.

Rand says BP's withdrawal is another triumph for the environmentalist group. But some observers believe that the oil company, and not Greenpeace, emerged as a narrow victor in this particular skirmish.

One oil industry source says BP probably

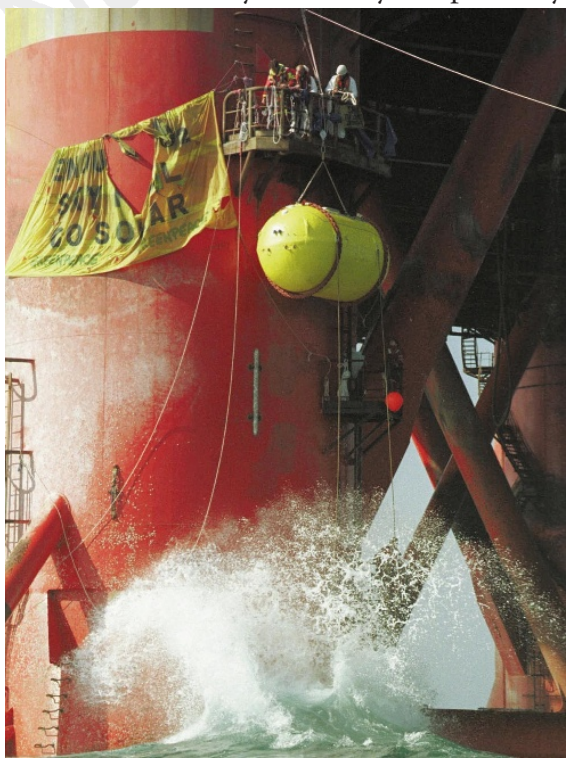

Chain gang: Greenpeace activists during their week-long occupation of the oil platform. never intended to carry out its threat of extracting damages, but sought to publicize the fact that Greenpeace was breaking the law. He says Greenpeace will have been wounded by being compelled to abandon an important weapon in its campaign arsenal: taking direct action.

But Rand says: "Direct action is a core value of Greenpeace, and will remain a core value. We have had injunctions served on us in the past, but they have not prevented us from taking direct action.

BP's court move could mark a shift in the oil industry's tactics in its battles with the environmentalist movement. It also suggests the industry learned valuable lessons in the wake of Shell's defeat at the hands of Greenpeace two years ago over its plans to sink the Brent Spar oil platform in the North Atlantic (see Nature 376, 378; 1995).

Greenpeace mobilized an international boycott of Shell petrol (gasoline) stations in response to Shell's insistence on deep-sea disposal of the oil platform. This time, BP gave Greenpeace no chance to organize another international campaign when it cancelled the writ for damages two days after it was issued.

Unusually for an oil company, BP has consistently sought to raise its public profile as an environmentally conscious enterprise. In May, it announced it would no longer oppose the scientific consensus that human activity was contributing to climate change — the first oil company to do so.

It also announced a significant increase in its investment in solar energy research and pulled out of the Global Climate Coalition, an association of oil and automobile companies that has voiced doubts about the scientific consensus on global warming.

But Greenpeace distrusts BP's environmentalist credentials, particularly because $\mathrm{BP}$ is one of 22 oil industry defendants in a separate action brought by Greenpeace, which asks the courts to investigate the legality of oil exploration licences given by the UK government on the Atlantic Frontier. Greenpeace claims that the UK government is in breach of European law as it did not conduct an environmental impact assessment before granting the licences.

$\mathrm{BP}$ has conducted its own private environmental impact assessment, which, a spokesman says, was the largest and most comprehensive of its kind. Sarah North, a Greenpeace marine campaigner, agrees, but says the study raises more questions than it answers. "There is no real analysis of the impact of spills on the coast, nor any specific data on the benthic organisms in the immediate vicinity of Foinaven."

\section{Karolinska Institute disowns work of cancer researcher}

[PARIS] The Karolinska Institute in Stockholm, Sweden, is distancing itself from the work of one of its former researchers, Ulf Lönn, six months after an independent panel of investigation concluded that he had "most probably" committed scientific fraud.

Lönn denies the charges. But, according to the investigation, about 20 papers published in the past decade by Lönn, who works on gene amplification in breast and bladder cancer, included data that appeared to have been manipulated. "A large number of Lönn's publications must be recalled and disclaimed as unreliable," says the report.

The Karolinska Institute is now considering introducing a compulsory system of archiving researchers' raw data with the aim of making manipulation more difficult.

The institute stops short of accusing Lönn formally of misconduct. Hans Wigzell, the vice-chancellor, says that from a legal point of view "we cannot conclude beyond all reasonable doubt that the data could not have come about by means other than fraud." Nonetheless, Wigzell says, the weight of evidence against the researcher is such that the institute has decided "not to stand by this research, because we consider it is irreproducible science". He will send letters to funding agencies and scientific journals this week explaining the conclusions of the investigation.

Suspicions were first raised early last year by one of Lönn's colleagues, who felt that the stream of publications emerging from his group exceeded what would be expected from the level of laboratory activity. Shortly afterwards, the institute set up a three-man panel of outside experts, chaired by Jan Pontén, professor of pathology at the University of Uppsala, to investigate the allegations. The panel delivered its report in February.

Lönn believes that he has been legally "cleared". His lawyer, Frederick Bostrom, from the Stockholm-based firm Lindwall and Nordbage, says that the investigation did not give the scientist "a fair chance" to defend himself, and he may bring a court case.

According to one scientist involved in the investigation, the Karolinska Institute took six months to react to the panel's finding because it was overly concerned about its image. The institute awards Nobel prizes in medicine and physiology. Pontén says that the institute should have alerted scientific journals to the allegations earlier.

Wigzell says the possibility of taking further action was complicated because the institute did not directly employ Lönn, who was funded by the health authorities. Lönn has recently left the institute. 